\title{
Jupiaba citrina, a new species from rio Aripuanã, rio Madeira basin, Amazonas and Mato Grosso States, Brazil (Characiformes: Characidae)
}

\author{
Angela M. Zanata ${ }^{1}$ and Willian M. Ohara ${ }^{2}$
}

A new species of Jupiaba Zanata is described from tributaries of the rio Aripuanã, rio Madeira basin, Amazonas and Mato Grosso States, Brazil. The new species can be diagnosed from its congeners (except J. abramoides, J. anteroides, and $J$. poranga) by having two vertically-elongated humeral blotches, the anterior usually with a darker median portion forming an horizontally-elongated trace pointed anteriorly, and a well defined dark longitudinal line extending from the second humeral blotch to the caudal peduncle. The new species differs from J. abramoides, J. anteroides, and J. poranga by having an elongated blotch over caudal peduncle that extends to the distal tip of the caudal-fin median rays. Also, it can be distinguished from most congeners by the combination of relatively high number of lateral line scales, predorsal median line without a series of scales, dentary teeth decreasing abruptly in size towards posterior portion, and presence of a larger central teeth cusp.

Uma nova espécie de Jupiaba Zanata é descrita de afluentes do rio Aripuanã, bacia do rio Madeira, Estados do Amazonas e Mato Grosso, Brasil. A nova espécie é diagnosticada de suas congêneres (exceto J. abramoides, J. anteroides e J. poranga) por apresentar duas manchas umerais alongadas verticalmente, a anterior usualmente com porção mediana mais escura formando um traço horizontalmente alongado, com projeção anterior, e uma linha escura bem definida estendendo-se da segunda mancha umeral até o pedúnculo caudal. A nova espécie difere de $J$. abramoides, $J$. anteroides, e $J$. poranga pela presença de uma mancha alongada sobre o pedúnculo caudal, que se estende até o final dos raios caudais medianos. Também pode ser diagnosticada da maioria das congêneres pela combinação de número relativamente alto de escamas na linha lateral, linha mediana pré-dorsal sem uma série de escamas, dentes do dentário decrescendo abruptamente em tamanho posteriormente e dentes com uma cúspide central maior que as demais.

Key words: Taxonomy, Small characid, Neotropical fish, South America.

\section{Introduction}

Jupiaba Zanata is a relatively small characid genus, with 25 described species that possess spine-like pelvic bones, protruding or not anteroventrally through the body wall (Birindelli et al., 2009). Most of Jupiaba species occurs in northern cisandean South America, with the distribution of a single species (J. acanthogaster (Eigenmann)) extending into the rio Paraguay basin and another (J. polylepis (Günther)) into the rio Parnaíba drainage in northeastern Brazil. Recent collecting efforts mainly on headwaters of various tributaries of the Amazon basin have been continuously revealing new species to the genus. Thus, we have recent descriptions of Jupiaba species from upper rio Tiquié, rio Negro basin (Zanata \& Lima, 2005), rio Tocantins basin (Pereira \& Lucinda, 2007), rio Xingu basin (Birindelli et al., 2009), and rio Tapajós and Madeira basins (Netto-Ferreira et al., 2009). Sampling on small streams of rio Aripuanã, rio Madeira basin, together with examination of institutional collections (INPA, MZUSP and UFMT) revealed at least four Jupiaba species to the area, J. anteroides (Géry), J. apenima Zanata, J. zonata (Eigenmann), and a new species described herein.

\section{Material and Methods}

Counts and measurements followed Fink \& Weitzman (1974) and Menezes \& Weitzman (1990). Measurements are given as proportions of standard length (SL) except for subunits of the head that are given as proportions of head length. Pelvic bone length measurement follows Weitzman \& Vari (1986). Meristic data are given in the descriptions, the frequency of each count is provided in parentheses after the

\footnotetext{
${ }^{1}$ Departamento de Zoologia, Instituto de Biologia, Universidade Federal da Bahia. Rua Barão de Geremoabo, s/n, Ondina, 40170-290 Salvador, BA, Brazil.zanata@yahoo.com.br

${ }^{2}$ Pós-Graduação em Biologia de Água Doce e Pesca Interior, Coordenação de Pesquisas em Biologia Aquática, Instituto Nacional de Pesquisas da Amazônia (INPA). Av. André Araújo 2936, Caixa Postal 478, 69011-970 Manaus, AM, Brazil. willianmohara@yahoo.com.br
} 
respective count, and an asterisk indicates counts of the holotype. Vertebrae, supraneurals, procurrent caudal-fin rays, branchiostegal rays, gill-rakers, and dentary teeth counts were taken only from cleared and stained paratypes (c\&s), prepared according to the method of Taylor \& Van Dyke (1985). Vertebrae of the Weberian apparatus were counted as four elements, included in the vertebral counts, and the fused PU1+U1 of the caudal region as a single element. Patterns of circuli and radii were defined on scales sampled from region between the lateral line and the insertion of dorsal fin. In the material listed, specimens are all alcohol preserved, except when indicated by c\&s. Institutional abbreviations follows Ferraris (2007), with the inclusion of UFBA (Universidade Federal da Bahia, Salvador, Brazil), NUP (Núcleo de Pesquisas em Limnologia, Ictiologia e Aquicultura, Maringá, Brazil), and UFMT (Universidade Federal do Mato Grosso, Cuiabá, Brazil).

Specimens not used for counts and measurements were treated as non-types.

\section{Jupiaba citrina, new species Figs. 1-3}

Holotype. INPA 32026, 60.5 mm SL, Brazil, Amazonas, Apuí, rio Madeira basin, middle rio Aripuanã drainage, igarapé on the left margin of the rio Guariba, Reserva Extrativista do Guariba, Mosaico do Apuí, 0846’31.0”S 60³1'27.7’W, 13 Nov 2008, F. R. V. Ribeiro \& T. F. Teixeira.

Paratypes. Brazil, Amazonas State, rio Madeira basin, rio Aripuanã drainage. INPA 32027, 16, 47.0-62.1 mm SL; MZUSP 101607, 3, 56.6-57.1 mm SL, collected with the holotype. INPA 32028, 10, 1 c\&s, 41.2-101.3 mm SL; MPEG 15530, 3, 56.6-57.1 mm SL, same locality and collectors as the holotype, 11 Nov 2008. Mato Grosso
State, rio Madeira basin, rio Aripuanã drainage. MZUSP 100542, 3, 47.8-54.9 mm SL, Aripuanã, rio Aripuanã, Balneário Primavera, below Dardanelos waterfall, 10¹0’06”S 059²6’50”W, 03 Apr 2004, F. A. Machado, C. M. C. Leite, N. E. Silva \& N. Flausino Jr. MZUSP 18676, 2, 50.3-78.9 mm SL, Igarapé do Porto, 0958’00”S 059¹9’00”W, 16 Nov 1976, Equipe de Ictiologia/INPA. UFBA 4688, 2, 46.8-53.1 mm SL, Colniza, igarapé on Parque Estadual Igarapés do Juruena, 0857’21.5”S 59²0’48.5”W, 27 May 2008, I. M. Fernandes \& N. Fausino Jr. UFBA 4687, 3, 51.2-58.8 mm SL, Colniza, igarapé on Parque Estadual Igarapés do Juruena, 0858’42.6”S 59²0’48.8”W, 27 May 2008, I. M. Fernandes \& N. Fausino Jr. UFBA 4689, 1, 51.0 mm SL, Colniza, igarapé on Parque Estadual Igarapés do Juruena, 0900’03.3”S 59¹4’44.6”W, 30 May 2008, I. M. Fernandes \& N. Fausino Jr.

Non-type material. Brazil, Mato Grosso State, Aripuanã, rio Madeira basin, rio Aripuanã drainage, stream tributary of rio Guariba. NUP 6761, 15, 35.3-50.5 mm SL, 1006'35”'S 59²6’12”W, 18-19 May 2008, I. M. Fernandes. NUP 6764, 2, 42.8-43.2 mm SL, 1004'47”S 59³1'04”W, 15 May 2008, I. M. Fernandes. NUP 6768, 6, 40.7-47.2 mm SL, 1003’57”S 59³’54”W, 15 May 2008, I. M. Fernandes.

Diagnosis. Jupiaba citrina is distinguished from its congeners (except J. abramoides (Eigenmann), J. anteroides, and $J$. poranga Zanata) by its color pattern, consisting of two vertically-elongated humeral blotches, the anterior usually with a darker median portion forming an horizontallyelongated trace pointed anteriorly, and a well defined dark longitudinal line extending from the second humeral blotch to the caudal peduncle. The new species differs from $J$. abramoides, $J$. anteroides, and $J$. poranga by having an horizontally-elongated blotch on caudal peduncle that extends continuously to the distal tip of the caudal-fin median rays (vs. dark line not forming blotch on caudal peduncle and

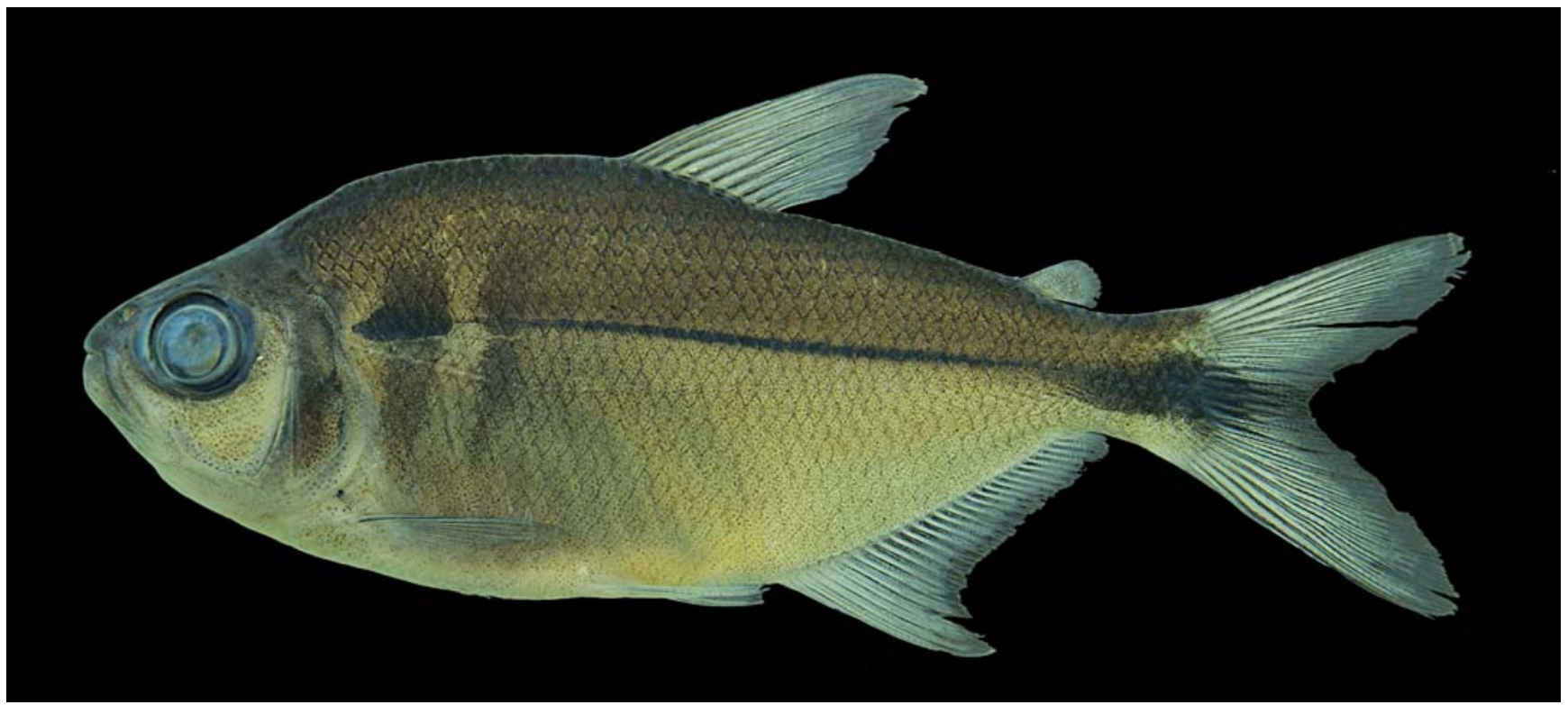

Fig. 1. Jupiaba citrina, holotype, INPA 32026, 60.5 mm SL, Brazil, Amazonas, Apuí, rio Aripuanã drainage, igarapé on the left margin of the rio Guariba. 
posterior end of this line isolated from dark blotch over caudalfin rays by a clear area). Jupiaba citrina differs from various congeners (except J. abramoides, J. anteroides, J. apenima, J. asymmetrica (Eigenmann), J. poranga, and J. yarina Zanata), by having the predorsal median area without a series of scales (vs. predorsal median area with a series of organized scales). Jupiaba citrina differs further from $J$. poranga and also $J$. yarina by its lower number of perforated scales (47-51 vs. 56-66) and lower number of scales between dorsal-fin origin and lateral line [10-11 (one specimen with 12) vs. 12-15] and between lateral line and origin of pelvic fin (8-9 vs. 10-13). From $J$. apenima it differs also by having lower number of perforated scales (47-51 vs. 55-59). The new species can be additionally distinguished from part of its congeners ( $J$. acanthogaster, J. atypindi Zanata, J. keithi (Géry et al.), J. maroniensis (Géry et al.), J. meunieri (Géry et al.), J. kurua Birindelli et al., J. minor (Travassos), J. pinnata (Eigenmann), and J. poekotero Zanata \& Lima) by having teeth with a distinctly larger median cusp and dentary teeth decreasing abruptly in size posteriorly (vs. median teeth cusp similar in size to the remaining cusps and dentary teeth decreasing gradually in size towards posterior portion). From the remaining species, J. citrina differs further from J. iasy (NettoFerreira et al.), J. mucronata (Eigenmann), J. ocellata (Géry et al.), J. paranatinga (Netto-Ferreira et al.), J. pirana Zanata, J. polylepis, J. potaroensis (Eigenmann), and J. zonata by having higher number of perforated scales (47-51 vs. 33-45), and from J. elassonaktis Pereira \& Lucinda, J. essequibensis (Eigenmann), and J. scologaster (Weitzman \& Vari) by having higher number of branched anal-fin rays (24-27 vs. 17-23).

Description. Morphometric data for the holotype and paratypes given in Table 1. Body somewhat compressed, moderately deep on larger specimens. Greatest body depth slightly anterior to dorsal-fin origin. Dorsal profile of head and body convex from upper lip to vertical through anterior

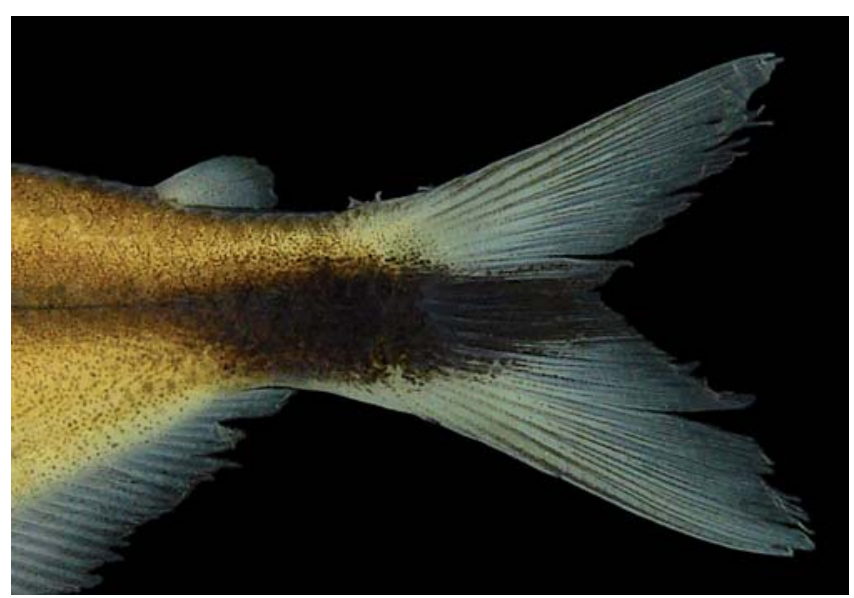

Fig. 2. Caudal fin of Jupiaba citrina, paratype, INPA 32027 , 48.8 mm SL, Brazil, Amazonas, Apuí, rio Aripuanã drainage, igarapé on the left margin of the rio Guariba. nares, straight to slightly concave from latter point to tip of supraoccipital spine, convex from tip of supraoccipital spine to terminus of dorsal-fin base, straight from latter point to adipose fin, and slightly concave between adipose fin and origin of anteriormost dorsal procurrent caudal-fin ray. Ventral profile of head and body convex from lower lip to anal-fin origin (in specimens with exserted pelvic bones, profile somewhat pointed around area of exsertion and nearly straight from portion along pelvic-spine to anal-fin origin), straight to slightly convex along anal-fin base, and slightly concave from terminus of anal-fin base to insertion of anteriormost ventral procurrent caudal-fin ray.

Jaws equal in length, mouth terminal. Posterior terminus of maxilla barely reaching vertical through anterior margin of orbit. Teeth robust (Fig. 3), cusps aligned along distal tooth margin. Premaxillary teeth in two rows; outer teeth row with four (4) or five (17) tricuspid teeth; inner teeth row with five (21) teeth bearing three to five cusps; symphyseal tooth of inner series comparatively narrow, asymmetrical, with lower number of cusps on medial side. Maxilla with one (4), two (13), or three (4) teeth bearing one or three cusps; anteriormost tooth usually the largest. Dentary with 12 (2) or 13 (1) teeth; four or five anteriormost teeth larger with five cusps; symphyseal tooth usually symmetrical; series of eight or nine posterior teeth abruptly smaller, with one or three cusps. Gillrakers on first gill arch seven (1), eight (1) or nine (1) on epibranchial, one (3) on cartilage between ceratobranchial and epibranchial, ten (3) on ceratobranchial, and two (2) or one (1) on hypobranchial. Branchiostegal rays four (3).

Scales cycloid, circuli distributed over whole area of scales, with none or few slightly divergent radii extending to

Table 1. Morphometric data of holotype and paratypes $(n=44)$ for Jupiaba citrina. SD = standard deviation.

\begin{tabular}{|c|c|c|c|c|}
\hline & Holotype & Range & Mean & SD \\
\hline Standard length (mm) & 60.5 & 41.8-101.3 & - & - \\
\hline \multicolumn{5}{|c|}{ Percents of standard length } \\
\hline Depth at dorsal-fin origin & 39.8 & $34.6-43.3$ & 38.2 & 1.7 \\
\hline Snout to dorsal fin origin & 50.6 & 48.3-53.3 & 50.7 & 1.0 \\
\hline Snout to pectoral-fin origin & 29.2 & 26.7-29.9 & 28.6 & 0.7 \\
\hline Snout to pelvic-fin origin & 50.8 & 46.1-50.9 & 48.6 & 1.3 \\
\hline Snout to anal-fin origin & 66.4 & $61.1-67.4$ & 65.0 & 1.5 \\
\hline Caudal-peduncle depth & 10.7 & $9.7-11.4$ & 10.6 & 0.4 \\
\hline Caudal-peduncle length & 12.7 & $10.7-14.3$ & 12.3 & 0.8 \\
\hline Pectoral-fin length & 20.6 & $19.3-22.7$ & 20.7 & 0.8 \\
\hline Pelvic-fin length & 17.5 & 15.7-18.5 & 17.1 & 0.7 \\
\hline Pelvic-bone length & 12.0 & 10.4-16.5 & 12.7 & 1.2 \\
\hline Dorsal-fin base length & 15.5 & $12.8-16.2$ & 14.6 & 0.8 \\
\hline Dorsal-fin height & 30.0 & 26.5-32.6 & 28.8 & 1.4 \\
\hline Anal-fin base length & 30.0 & 28.2-32.8 & 30.2 & 1.2 \\
\hline Anal-fin lobe length & 20.6 & $17.6-22.5$ & 20.1 & 1.1 \\
\hline Eye to dorsal-fin origin & 38.9 & $35.4-40.1$ & 37.1 & 1.1 \\
\hline Dorsal-fin origin to caudal-fin base & 53.5 & $52.1-57.8$ & 54.7 & 1.3 \\
\hline Head length & 50.1 & 44.5-53.6 & 48.4 & 1.9 \\
\hline \multicolumn{5}{|c|}{ Percents of head length } \\
\hline Horizontal eye diameter & 37.7 & $30.1-41.0$ & 35.7 & 3.0 \\
\hline Snout length & 27.3 & 24.1-29.9 & 27.1 & 1.4 \\
\hline Least interorbital width & 34.9 & 30.5-38.6 & 34.3 & 1.5 \\
\hline Upper jaw length & 46.9 & $41.0-49.2$ & 44.9 & 2.0 \\
\hline
\end{tabular}


posterior margin of scales. Lateral line slightly curved ventrally, 47 (1), 48 (3), 49 (12), 50* (16), or 51 (6) perforated scales continuous from supracleithrum to base of caudal fin. Longitudinal scale rows between dorsal-fin origin and lateral line 10 (8), $11^{*}$ (21) or 12 (1). Longitudinal scale rows between lateral line and pelvic-fin origin eight (26)* or nine (3). Median series of scales along middorsal line between tip of supraoccipital process and origin of dorsal fin absent. Circumpeduncular scales 18 (19) or 19 (6)*. Single row of six to nine scales covering base of anteriormost anal-fin rays.

Dorsal-fin rays ii,9* (42); distal margin of dorsal fin straight to slightly rounded. Dorsal-fin origin around middle of standard length; first dorsal-fin pterygiophore inserting posterior to neural spine of $9^{\text {th }}$ (3) vertebra and insertion of dorsal fin posterior to vertical through pelvic-fin origin. Adipose fin present. Anal-fin rays iv or v, 24 (15), 25 (19), 26* (9), or 27 (1); distal margin of anal fin concave; first anal-fin pterygiophore inserting posterior to haemal spine of $16^{\text {th }}$ (3) vertebra. Pectoral-fin rays i, 11 (5), 12 (17), 13* (16) or 14 (1); tip of pectoral fin not reaching pelvic-fin origin. Pelvic-fin rays i,7 (41); pelvic bone elongate, modified into spine, with anterior portion diverging (in relation to its counterpart) but usually not protruding through body wall. Principal caudalfin rays 10+9 (13); caudal fin forked, lobes somewhat pointed, of similar size. Eleven (1) or 12 (2) dorsal procurrent caudal-fin rays, and nine (1) or ten (2) ventral procurrent caudal-fin rays. Vertebrae 33 (3). Supraneurals four (2) or five (1).

Color in alcohol. Ground color yellowish to tan, darker dorsally (Fig. 1). Small dark chromatophores densely concentrated on

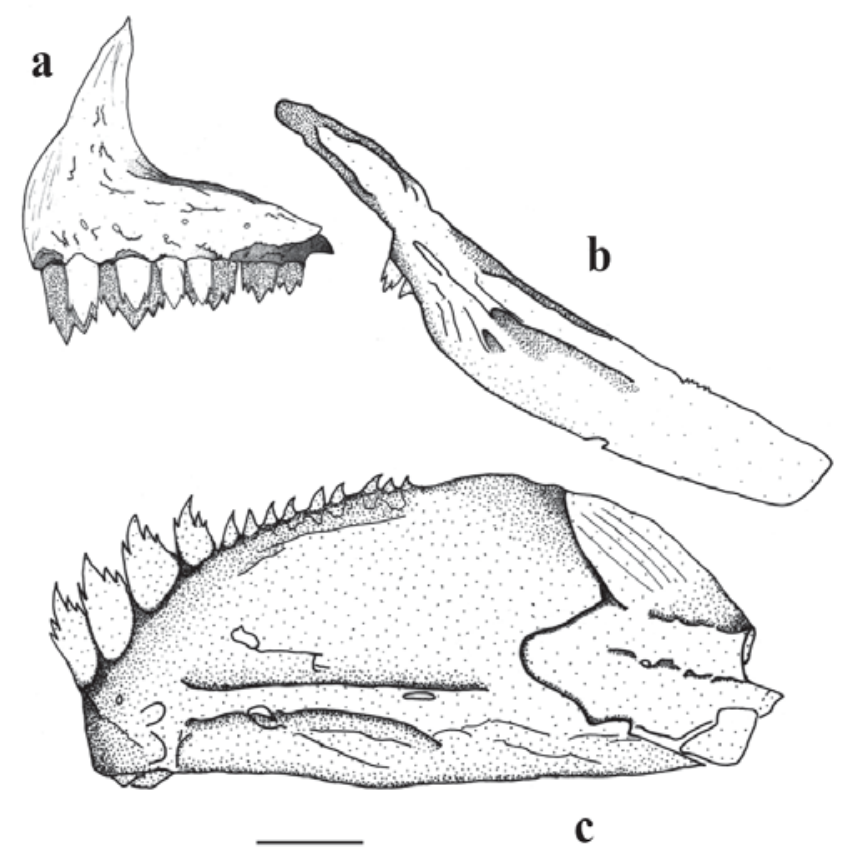

Fig. 3. Premaxilla (a), maxilla (b) and dentary (c) of Jupiaba citrina, paratype, INPA 32028, 57.7 mm SL; lateral view; left side. Scale bar $=1 \mathrm{~mm}$. dorsal surface of head from upper lip to supraoccipital spine; dense pigmentation continuing posteriorly throughout middorsal line of body. Maxilla, infraorbitals, and opercle with scattered dark chromatophores; some specimens with small chromatophores more concentrated on region close to orbit and on upper half of opercle. Ventral portion of head less pigmented than dorsal portion; snout and maxilla tan.

Larger and darker chromatophores sparsely distributed along scales posterior borders, forming a mild reticulate pattern on most of fish body; overall amount of chromatophores reducing gradually through ventral portion resulting in a less conspicuous reticulate pattern. Scales of dorsal portion of body darkened, with patches of relatively small dark chromatophores on its central portion. Abdominal region yellowish, with a few small chromatophores sparsely distributed. Humeral region with two well-defined verticallyelongated blotches, separated by a clearer area. First blotch more evident, situated on the first five or six scales, counted on series just above the lateral line, and extending to about ten vertical series of scales; central portion of blotch with concentration of subjacent darker pigment, forming a black horizontal narrow bar (with nearly twice the width of dark longitudinal line) that extends anteriorly to reach the first scale series behind opercle and is interrupted posteriorly by the clearer area. Dorsal portion of first blotch darker and separated from ventral portion by an unpigmented horizontal thin line just below the horizontal bar. Second humeral blotch situated on area of seven to nine scales, counted on series just above the lateral line, vertically covering nine to eleven series of scales, and horizontally covering three or four scales on its widest portion. A well defined straight dark line extends from rear of second humeral blotch to caudal peduncle, where it becomes enlarged and forms an elongated blotch that extends to the distal tip of the median caudal-fin rays (Fig. 2); dark line positioned above the lateral line (with width approximately half the height of the scale), formed by subjacent dark pigment, and aligned to the horizontal trace of first humeral blotch. Blotch on caudal peduncle restricted to area posterior to vertical through adipose-fin insertion; in most specimens this blotch covers one or two scales row above and below the lateral line; blotch somewhat ventrally displaced in various specimens.

Dorsal fin somewhat dusky, with rays outlined by small, dark chromatophores. Anal, pectoral, and pelvic fins darkened in a similar pattern as dorsal fin, but with chromatophores more sparsely distributed, not forming lines along rays; anal fin in some specimens with concentration of dark chromatophores on interradial membranes of proximal portion of rays. Caudal fin with rays outlined by small, dark chromatophores; up to seven median rays and interradial membranes darkened by the caudal blotch. Adipose fin with scattered dark chromatophores.

Color in life. Overall body coloration silvery, with guanine covering lateral and ventral surfaces of head, ventral and lateral portions of body, and anteroventral portion of caudal peduncle. 
Head and body with iridescent hues of blue and green; head also with golden hues. Areas around posterodorsal portion of head, opercle, pectoral-fin insertion, snout and iris orangeyellowish; dorsalmost portion of iris red. Dorsal portions of head and body somewhat dark. Central portion of first humeral blotch distinctly visible and remaining areas of humeral blotches inconspicuous. Dark longitudinal midline and caudal-peduncle blotch poorly visible. Median caudal-fin rays black. All fins orange-reddish, except for the yellow pectoral.

Sexual dimorphism. Secondary sexual characters were not observed on examined specimens.

Geographic distribution and ecological notes. Jupiaba citrina is known from the rio Aripuanã drainage, rio Madeira basin. Specimens were sampled from two distinct habitats, represented by igarapés of Parque Estadual Igarapés do Juruena, on northwest of Mato Grosso State, and igarapés of Reserva Extrativista do Guariba, on southeast Amazonas State, Brazil (Fig. 4). Specimens of J. citrina from Amazonas State were found in small black water igarapé $2.5 \mathrm{~m}$ wide and $0.5 \mathrm{~m}$ deep, with preserved riparian vegetation, slow water current, bottom with sand and pebbles, $\mathrm{pH} 5.5$ and water temperature of $26^{\circ} \mathrm{C}$. Other species sampled syntopically are Aequidens cf. palidus, Aequidens tetramerus, Apistograma aff. linkei, Crenicichla pellegrini, Crenicichla proteus, Characidium sp., Erythrinus erythrinus, Gymnotus anguillaris, Gymnotus sp., Helogenes marmoratus, Hoplias malabaricus, Hyphessobrycon aff. agulha, Megalechis picta,

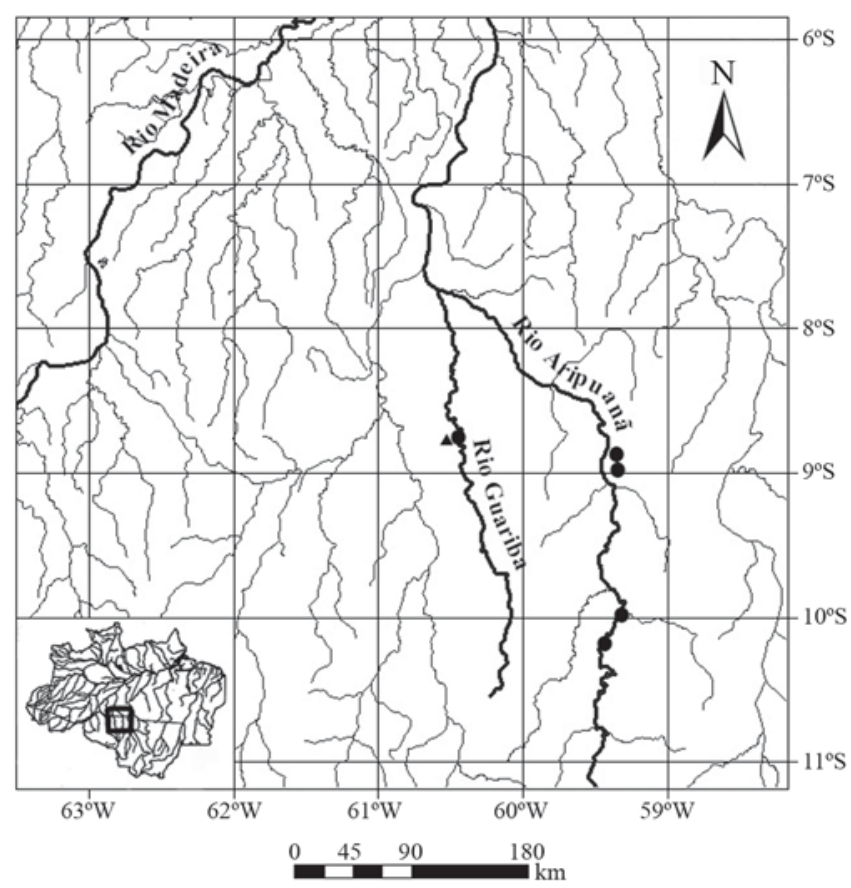

Fig. 4. Geographical distribution of Jupiaba citrina. Each symbol may represent more than one sample or locality. Triangle indicates the type-locality.
Moenkhausia oligolepis, Nemuroglanis sp., and Rhamdia quelen. Specimens from northwest of Mato Grosso State were sampled in various clear water igarapés of Parque Estadual Igarapés do Juruena, with sandy bottom and deposits of organic matter, up to 3 meters wide and around $0.6 \mathrm{~m}$ deep, and well preserved riparian vegetation. At this location, Jupiaba citrina was sampled syntopically with a series of fish species, including two congeners, J. anteroides and J. apenima, and a somewhat similarly colored species of Moenkhausia.

The analysis of the stomach contents of three paratypes revealed presence of ants, larvae of Diptera (chironomid), Trichoptera, nematods, unidentified insect fragments, filamentous algae, unidentified vegetal fragments and sediments. The species apparently has omnivorous and opportunistic feeding habits.

Etymology. From the Latin citrus, meaning lemon, orange, in allusion to the orange-yellowish coloration of body portions of the species in life.

Remarks. Jupiaba citrina apparently belongs to a putative group of Jupiaba, including J. abramoides, J. anteroides, J. apenima, J. asymmetrica, J. poranga, and J. yarina, which share a series of external features, as absence of series of scales on predorsal median area, elevated number of body scales (43-66), and a relatively long pelvic bone (9.6-17.2\%). Within this group of species, Jupiaba abramoides, J. anteroides, J. poranga, and J. citrina share the uncommon possession of two well defined vertically-elongated humeral blotches (the first with a central darker horizontal portion anteriorly-elongated) followed by a well defined black line, which may indicate a close relationship between these forms. Distinction on coloration of these species is mainly restricted to the caudal peduncle area (see Diagnosis). Jupiaba apenima, J. asymmetrica, and J. yarina do not have the details of body coloration described for the four species cited above, but, on the other hand, possess an horizontally-elongated blotch on caudal peduncle somewhat similar to that observed in specimens of $J$. citrina.

The new species occurs simpatrically with a somewhat similarly colored species of Moenkhausia, yet to be described. Resemblance on overall body shape and coloration of Jupiaba with other small characid species was previously discussed by Zanata et al. (in press), who putatively interpreted the remarkable similarities among Jupiaba yarina, J. apenima, and Moenkhausia sp. as a mimicry association. Up to date, cases of possible mimicry with Jupiaba species are known only to the group that $J$. citrina putatively belongs ( $J$. abramoides, J. anteroides, J. apenima, J. asymmetrica, J. poranga, J. yarina). Thus, other cases of characids mimicking species of Jupiaba involves J. abramoides, J. anteroides and Astyanax anterior Eigenmann, observed in sympatry in the rio Tiquié, upper rio Negro, and Astyanax sp. with $J$. anteroides and $J$. poranga in tributaries of the rio Teles Pires (Zanata et al., in press).

Jupiaba citrina is possibly endemic to the rio Aripuanã 
drainage. The apparently high degree of endemism of the area was already discussed elsewhere, with about ten endemic described species suggested by Kullander (1995) and Benine (2002). Recent collecting efforts resulting from various inventory projects carried out on rio Aripuanã drainage continuously reveal new and possibly endemic fish species (Rocha et al., 2008a, 2008b; present paper), attesting the importance of new investigations of its ichthyofauna and conservation of the area.

Comparative material examined. In addition to data from species of Jupiaba cited under Zanata (1997) publication, the following material was utilized for the comparative study: Jupiaba anteroides: Brazil, Mato Grosso, rio Madeira basin: UFBA 4691, 3, 76.6-91.8 mm SL; UFBA 4690, 1, 58.7 mm SL. Amazonas, rio Madeira basin: INPA 26228, 12, 50.4-73.7 mm SL. Jupiaba apenima MZUSP 91693, 3, 48.5-58.7 mm SL, Brazil, Mato Grosso, rio Xingu basin. Jupiaba asymmetrica INPA 26422, 7, 31.2-39.4 mm SL, Brazil, Amazonas, rio Madeira basin. Jupiaba cf. poranga: Brazil, Mato Grosso, rio Tapajós basin: UFBA 4695, 14, 26.8-49.2 mm SL; UFBA 4696, 12, 32.7-51.1 mm SL. Jupiaba zonata: Brazil, Amazonas, rio Madeira basin: INPA 26426, 6, 30.9-38.7 mm SL; INPA 26288, 2, 30.1-34.0 mm SL. Moenkhausia sp.: Brazil, Mato Grosso, rio Madeira basin: UFBA 4698, 1, 43.4 mm SL; UFBA 4699, 1, 55.8 mm SL.

\section{Acknowledgements}

For loan or donation of specimens we thank Osvaldo T. Oyakawa (MZUSP), Alexandre Ribeiro (UFMT), and Cláudio H. Zawadzki (UEM). We are grateful to Izaías M. Fernandes (UFMT) for the help with specimens from Mato Grosso State, Frank Ribeiro (INPA) for his help and assistance during the field expedition, Andre Canto (INPA) and Bruno Luize (INPA) for help with the photograph of the holotype and Figure 4, respectively, Ilse Walker (INPA) for the help with the identification of the stomach contents, Wellington Pedroza (INPA) who kindly prepared illustration of Fig. 2, and Túlio F. Teixeira (INPA) by the photography of Jupiaba citrina that allowed the description of the coloration in life. Thanks particularly to the Secretaria de Desenvolvimento Sustentável do Amazonas (SDS), Fundo Brasileiro para a Biodiversidade (FUNBIO), INPA and UFBA for financial and logistic support. WMO has a master fellowship from Coordenação de Aperfeiçoamento de Pessoal de Nível Superior (CAPES).

\section{Literature Cited}

Benine, R. C. 2002. Moenkhausia levidorsa, a new species from Rio Aripuanã, Amazon Basin, Brazil (Characiformes: Characidae). Ichthyological Exploration of Freshwaters, 13(4): 289-294.

Birindelli, J. L. O., A. M. Zanata, L. M. Sousa \& A. L. NettoFerreira. 2009. New species of Jupiaba Zanata (Characiformes: Characidae) from Serra do Cachimbo, Brazil, with comments on the distribution of Jupiaba meunieri and the endemism of upper rio Curuá. Neotropical Ichthyology, 7(1): 11-18.

Ferraris C. J. Jr. 2007. Checklist of catfishes, recent and fossil (Osteichthyes: Siluriformes), and catalogue of siluriform primary types. Zootaxa, 1418: 1-628.
Fink, W. L. \& S. H. Weitzman. 1974. The so-called cheirodontin fishes of Central America with description of two new species (Pisces, Characidae). Smithsonian Contributions to Zoology, 172: 1-46.

Kullander, S. O. 1995. Three new cichlid species from southern Amazonia: Aequidens gecilae, A. epae and A. michaeli. Ichthyological Exploration of Freshwaters, 6(2): 149-170.

Menezes, N. A. \& S. H. Weitzman. 1990. Two new species of Mimagoniates (Teleostei: Characidae: Glandulocaudinae), their phylogeny and biogeography and a key to the glandulocaudin fishes of Brazil and Paraguay. Proceedings of the Biological Society of Washington, 103: 380-426.

Netto-Ferreira, A. L., A. M. Zanata, J. L. O. Birindelli \& L. M. Sousa. 2009. Two new species of Jupiaba (Characiformes: Characidae) from the rio Tapajós and rio Madeira drainages, Brazil. Zootaxa, 2262: 53-68.

Pereira, T. N. A. \& P. F. Lucinda. 2007. A new species of Jupiaba Zanata, 1997 (Ostariophysi, Characiformes, Characidae) from the rio Tocantins drainage, Brazil. Zootaxa, 1614: 53-60.

Rocha, M. S., R. R. Oliveira \& L. H. Rapp Py-Daniel. 2008a. A new species of Gladioglanis Ferraris \& Mago-Leccia from rio Aripuanã, Amazonas, Brazil (Siluriformes: Heptapteridae). Neotropical Ichthyology, 6(3): 433-438.

Rocha, M. S., R. R. Oliveira \& L. H. Rapp Py-Daniel. 2008b. Scoloplax baskini: a new spiny dwarf catfish from rio Aripuanã, Amazonas, Brazil (Loricarioidei: Scoloplacidae). Neotropical Ichthyology, 6(3): 323-328.

Taylor, W. R. \& G. C. Van Dyke. 1985. Revised procedures for staining and clearing small fishes and other vertebrates for bone and cartilage study. Cybium, 9: 107-109.

Weitzman, M. J. \& R. P. Vari. 1986. Astyanax scologaster, a new characid (Pisces: Ostariophysi) from the Rio Negro, South America. Proceedings of the Biological Society of Washington, 99(4): 709-716.

Zanata, A. M., J. L. O. Birindelli \& C. R. Moreira. (in press). New species of Moenkhausia Eigenmann (Characiformes: Characidae) from Xingu and Tapajós river basins, Brazil, with comments on a putative case of polymorphic Batesian mimicry. Journal of Fish Biology.

Zanata, A. M. \& F. C. T. Lima. 2005. New species of Jupiaba (Characiformes: Characidae) from Rio Tiquié, Upper Rio Negro Basin, Brazil. Copeia, 2005(2): 272-278.

Accepted August 18, 2009 Published December 18, 2009 